\title{
An Analysis of the Consumption of Sausages in Scotland Using Supermarket Data
}

\author{
Cesar Revoredo-Giha ${ }^{1 *}$, Beata Kupiec-Teahan ${ }^{1}$, Wendy Wrieden ${ }^{2}$, Victoria Davis ${ }^{3}$, Philip Leat ${ }^{4}$ \\ ${ }^{1}$ Food Marketing Research, Scottish Agricultural College, Edinburgh, UK; ${ }^{2}$ School of Pharmacy and Life Sciences, Robert Gordon \\ University, Aberdeen, Scotland; ${ }^{3}$ School of Health Sciences, Robert Gordon University, Aberdeen, Scotland; ${ }^{4}$ Food Marketing Re- \\ search, Scottish Agricultural College, Aberdeen, Scotland. \\ Email: ${ }^{*}$ Cesar.Revoredo@sac.ac.uk
}

Received April $7^{\text {th }}, 2012$; revised May $11^{\text {th }}, 2012$; accepted May $18^{\text {th }}, 2012$

\begin{abstract}
This paper addresses consumers' choices by examining: current food choices made by different socio-economic groups; price barriers to diet improvement; and ways in which marketing may affect product choice. The study seeks: first, to analyze the differences in consumption of sausages of different nutritional composition among different socio-demographic and lifestage groups; and second, using the example of sausages, to measure whether it is possible to improve diet quality without affecting household expenditure. Sausages represent a relatively high proportion of red and processed meat purchases in Scotland, contributing significantly to the fat and sodium in the Scottish diet. The data used consisted of two-years of weekly information from a top-4, UK supermarket. The results suggest that it is possible to purchase the same amount of a lower saturated fat or lower sodium sausage for the same price as a higher saturated fat or sodium sausage. However, it would cost more for some of the groups to replace a sausage that was both higher in saturated fat and higher in sodium with a lower saturated fat, lower sodium version in the household's food basket.
\end{abstract}

Keywords: Scotland; Saturated Fats; Sodium; Consumer Choices; Sausages Consumption

\section{Introduction}

Diet has an impact on health and in turn the public budget; therefore, it is important to track changes in the population's diet and in sub-groups of the population so as to enable the targeting of appropriate healthier eating advice and interventions. As supermarket chains dominate food sales in the UK, data from these outlets regarding purchases of different products by different groups is very useful for tracking consumers' choices.

This paper derives from the project "An Exploration of the Use of a Dataset of Supermarket Purchases for the Analysis of Red Meat Purchases in Scotland" [1] commissioned by the Food Standards Agency Scotland (FSAS). It has the purpose of analysing the choice of sausages according to their nutritional characteristics, and to assess whether it is possible to improve the nutriational quality of the choice without increasing consumer expenditure in the sausage category.

The choice of sausages for the analysis was due to two reasons. First, they represent an important component of red meat purchases in Scotland. Second, sausages are also quite variable in terms of their fat and sodium content. Differences in the composition of the purchases by

"Corresponding author. different sub-groups of the population might therefore be important from a health perspective. Furthermore, fat and sodium (salt) intake have been identified as aspects of the UK and Scottish diet to be targeted for change [2].

A survey of meat products in Scotland showed that the nutritional composition of meat products was wide [3]; however, it did not consider the cost of the sausages. The expenditure dimension is important, as pointed out by [4], as promotion of high-cost foods to low-income consumers, without taking food costs into account, is unlikely to be successful. It is important to note that the current difficult economic situation may have triggered an increase in the consumption of sausages. The UK food and grocery market grew (in current value terms) by 4.9 percent over 2008, with growth driven by rapid food price inflation [5]. In response to this, consumers started controlling their spending more and modified their purchase behaviour. In 2006 UK consumers spent more on meat than on any other category of food ( $£ 14 \mathrm{bn})$, with the exception of fruit and vegetables (which accounted for $£ 15.5$ bn of consumer expenditure that year). As sausages are a cheaper alternative to most meat cuts and bacon, significant increases in food prices may have stimulated the purchases of sausages. Indeed, there was a 
2 percent increase in the quantity of sausages purchased in the UK between 2008 and 2009 [6]. In the same period, the average price of sausages increased by 12 percent and expenditure by 11 percent. It should be noted that fresh and frozen meat purchases went down by 2 percent, with prices increasing by 10 percent and expenditure by 8 percent [7]. At present sausages belong to the so-called "Cheapest On Display" (COD) food; the category occupying more shelf space, as most consumers want to buy their staple food cheaply [8]. Meat in the COD food category, apart from sausages, includes processed red meat products such as tinned meat and pies.

Lowering the level of fat in sausages can significantly decrease their energy, saturated fat and cholesterol content, which increases the risk of obesity and heart disease [9-11]. Low sodium products help to decrease its level in the human body, improving the cardiovascular system, especially with regards to lowering blood pressure $[7,12]$. However, the change to lower fat and lower salt products is not simple, as besides the nutrition and health aspect of fat and salt reduction; the changes also have an impact on sensory, safety, technological, legal and possi- bly cost factors [13].

The structure of the paper is as follows: it starts with a literature review of sausage consumption; next, the paper's methodology is presented, followed by results and discussion. Finally, conclusions are presented.

\section{Literature Review}

The diet in Scotland, together with smoking, has been cited as one of the main contributors to high rates of chronic diseases such as coronary heart disease, obesity, type 2 diabetes, hypertension, stroke and certain types of cancer [2,14-17].

A report on the Scottish Diet [14] identified targets for reducing consumption of processed red meat. It was recommended that the intake of processed red meat and sausages should be halved and the intake of bacon and ham should be decreased by 20 percent. These recommendations were aiming to reduce the intake of fat and saturated fatty acids, which are thought to be contributing to high rates of heart disease and obesity. Also, the World Cancer Research Fund [18] highlighted the evidence that consumption of red and processed red meat is likely to increase the risk of colorectal cancer and recommended to limit the consumption of red meats (mainly beef, pork and lamb) and avoid consumption of processed meats (see also [17]). Research into healthy food consumption and cancer interdependence is especially important for decision makers in developed countries where adverse dietary patterns are prevalent [19].

A review of food consumption in Scotland carried out in 2006 [20] and based on Expenditure and Food Survey
(EFS) 2003/2004 data, showed that the population's mean consumption of processed red meat (including burgers and meat pies) and sausages and bacon and ham had actually increased. For processed ham and sausages the mean consumption in 2003/2004 was 55 g per week, whilst in 1996 it was $52 \mathrm{~g}$ per week, and for bacon and ham was 16 g per week in 2003/2004 in comparison to $12 \mathrm{~g}$ per week in 1996.

The aforementioned review also showed that higher amounts of processed meat and sausages were consumed in more deprived areas. The consumption of processed meat was higher in the consumer segments with lower affluence; the mean consumption was $64 \mathrm{~g}$ a week in the lowest quintile of the Scottish Index of Multiple Deprivation (SIMD) [21].

Overall, higher-quality diets are associated with higher income, higher socio-economic status and education. Energy-dense (nutrient-poor) diets are associated with lower socio-economic groups with limited disposable income [22]. Personal disposable income (PDI) therefore, is a major predictor used to forecast consumption of nutrient-rich foods, as it determines the consumers' ability and willingness to trade up to premium, higher value options and to absorb any price rises. Red meat is a particular example of such foods. Recent trends indicate that consumers are reducing expenditure on more expensive meat cuts and meat products, and looking for cheaper outlets in order to control household food budgets [6].

While socio-economic differences in dietary intake are well documented, relatively little is known about their underlying causes. Amongst the reasons for such variations may be the cost differentials between energy-dense and nutrient-dense foods [23], physical access to healthy food options (neighbourhood effect), acquired taste (sensory preferences) and nutritional habits and traditions [24]. For example, in the UK 25 percent of red meat consumers consider red meat consumption as driven by taste and cannot see any alternative to this product category. Men tend to be more loyal to specific meat product categories and have their preferences rooted firmly in nutritional habits acquired in childhood and adolescence. Consumer preferences differ in different regions. For example, there are specific differences between Scotland and the rest of the UK with regards to specific meat products, such as canned meat or Scottish preference for locally produced lamb and beef [25].

Sensory preferences and familiarity with the product are also important factors that are likely to affect especially repeated purchase decision. Different groups of consumers are likely to react differently to the information about fat and or salt reduction, e.g. women usually being more sensitive to fat reduction incentive [26] consumers in general having a positive attitude towards premium products [27]. In palatabilty and preference 
tests, low fat/low salt sausages can easily be liked by consumers under the condition that the sensory characteristics are close enough to the standard recipe products [28]. In the UK, consumer tests have shown that low fat sausages can achieve the same level of likeability as their standard counterparts [29].

\section{Methodology}

\subsection{Data}

The data used for the analysis were provided by the Centre for Value Chain Research $\left(\mathrm{VCR}^{2}\right)$, Kent Business School for the study "An Exploration of the Use of a Dataset of Supermarket Purchases for the Analysis of Red Meat Purchases in Scotland" [1]. They consisted of two-years of weekly information (corresponding approximately to the years 2007 and 2008) from a major supermarket chain (amongst the top-4 multipe retailers in the UK). These were aggregated-over-customers data supplied in bespoke reports. The raw data (the raw panel dataset with information for each customer) were not accessible. It is important to note that the recorded transactions derived from a sample of customers owning and using a loyalty card.

The data on purchases of sausages included four variables namely: total expenditure (in GBP, i.e., £); number of purchased units; number of customers and price (£/unit). In addition, information about the total number of customers purchasing sausages for each one of the groups analysed was extracted.

The list of sausages in the database was sorted according to the expenditure on them. From the universe of sausages, only those accounting for 0.5 percent or more of the total expenditure on sausages were used in the analysis. For the selected set of sausages (i.e., 49 types of sausages), information about their nutritional content was collected from the manufacturer or supermarket websites and product labels. This information consisted of three indicators: percentage of energy derived from saturated fat, sodium content per $100 \mathrm{~g}$ and price per $100 \mathrm{~g}$.

The data were available according to two different classifications: lifestage and a geo-demographic classification CAMEO. Tables 1 and 2 present the two classifications with a brief explanation of the categories. It should be noted that although there was a description for all categories in the two classifications, there was not a quantitative description of the categories. For instance, there was no available information on the number of members in the households, number of children, etc. This was a shortcoming of the dataset for its use in the analysis of nutritional issues.

\subsection{Methods}

The methodology used consisted of studying the expen-
Table 1. Lifestage classification of customers.

\begin{tabular}{lcl}
\hline $\begin{array}{c}\text { Lifestage } \\
\text { segment }\end{array}$ & $\begin{array}{c}\text { Percentage } \\
\text { of customers }\end{array}$ & \multicolumn{1}{c}{ Age and family } \\
\hline Young adults & 14.5 & Adults aged 20 - 39 with no children \\
Older adults & 14.0 & Adults aged 40 - 59 with no children \\
Young families & 16.8 & Adults with all children under 10 \\
Older families & 15.7 & Adults with one or more children over 10 \\
Pensioners & 10.7 & Adults over 60 with no children \\
Mixed & 28.4 & Multigenerational households \\
\hline
\end{tabular}

Source: The Centre for Value Chain Research $\left(\mathrm{VCR}^{2}\right)$, Kent Business School.

diture of each group (i.e., CAMEO and lifestage) against a healthy "frontier" of sausages based on two indicators: the percentage of energy derived from saturated fat, and the sodium content per $100 \mathrm{~g}$. This helped to identify the healthiest choice considering only one of the mentioned indicators.

Figure 1 represents the type of analysis conducted. The blue dots represents the top 10 sausages in terms of expenditure (and the red the remaining ones). The sausage named as "B" was the healthiest one as it had both the lowest percentage of energy derived from saturated fat, and the lowest sodium content per $100 \mathrm{~g}$. Thus, the focus of the analysis was to study the movement, in terms of expenditure, from the blue dots to the dot " $\mathrm{B}$ ".

As regards the groups used in the Tables: Lifestage groups in the table are: Group 1-Older Families, Group 2 - Older Adults and Others, Group 3-Pensioners, Group 4-Young Adults (Inc. Students), Group 5-Young Families. The CAMEO groups in the Table are: Group $1-$ Affluent Home-Owners, Group 2-Comfortable Mixed Neighbourhoods, Group 3-Less Affluent Families, Group 4-Less Affluent Singles and Students, Group 5-Poorer Council Tenants-Many Single Parents, Group 6-Poorer Family and Single Parent Households, Group 7-Poorer White and Blue Collar Workers, Group 8-Smaller Private Family Homes, Group 9-Wealthy Retired Neighbourhoods, Group 10-Young and Affluent Singles.

In Figure $\mathbf{1}$ is possible to observe the considerable variety that exists in fat and sodium content amongst sausages. Note that the top-10 sausages are not concentrated in similar content of fat and sodium but scattered around. This pattern may indicate the influence of tastes over different types of sausages.

\section{Results and Discussion}

Figures 2 and 3 present the relationships between percentage energy from saturated fat and price per $100 \mathrm{~g}$ and sodium per $100 \mathrm{~g}$, respectively.

Two aspects are worth noting from the figures: first, there is no clear relationship between price and saturated 
Table 2. The CAMEO UK classification.

\begin{tabular}{|c|c|c|c|c|c|c|c|c|}
\hline CAMEO UK type & $\begin{array}{l}\text { Percentage } \\
\text { of UK } \\
\text { households }\end{array}$ & $\begin{array}{l}\text { Child } \\
\text { age }\end{array}$ & $\begin{array}{l}\text { Adult } \\
\text { age }\end{array}$ & $\begin{array}{l}\text { Family } \\
\text { composition }\end{array}$ & Housing type & $\begin{array}{c}\text { Geographical } \\
\text { area }\end{array}$ & Qualifications & $\begin{array}{l}\text { Employment } \\
\text { type }\end{array}$ \\
\hline $\begin{array}{l}\text { Affluent singles and } \\
\text { couples in exclusive } \\
\text { urban } \\
\text { neighbourhoods }\end{array}$ & 3.44 & $\begin{array}{l}\text { Few } \\
\text { children }\end{array}$ & $\begin{array}{c}20-59 \\
\mathrm{yr}\end{array}$ & Single, couples & Terraced/flats & $\begin{array}{l}\text { Inner } \\
\text { city/suburbs }\end{array}$ & Very high & $\begin{array}{l}\text { Professional/white } \\
\text { collar }\end{array}$ \\
\hline $\begin{array}{l}\text { Wealthy } \\
\text { neighbourhoods } \\
\text { nearing and } \\
\text { enjoying retirement }\end{array}$ & 3.64 & $\begin{array}{c}5-15 \\
\mathrm{yr}\end{array}$ & $\begin{array}{c}40+ \\
\mathrm{yr}\end{array}$ & $\begin{array}{l}\text { Older singles, } \\
\text { Couples, } \\
\text { families }\end{array}$ & Detached/semi-detached & Suburbs/rural & High & $\begin{array}{l}\text { Professional/white } \\
\text { collar }\end{array}$ \\
\hline $\begin{array}{l}\text { Affluent home } \\
\text { owning couples and } \\
\text { families in large } \\
\text { houses }\end{array}$ & 10.14 & $\begin{array}{c}5-19 \\
\mathrm{yr}\end{array}$ & $\begin{array}{c}30-64 \\
\mathrm{yr}\end{array}$ & $\begin{array}{l}\text { Couples, } \\
\text { families }\end{array}$ & Detached/semi-detached & Rural & $\begin{array}{l}\text { Above } \\
\text { average }\end{array}$ & $\begin{array}{l}\text { Professional/blue } \\
\text { white collar }\end{array}$ \\
\hline $\begin{array}{l}\text { Suburban } \\
\text { homeowners in } \\
\text { smaller private } \\
\text { family homes }\end{array}$ & 13.27 & $\begin{array}{l}0-15 \\
\mathrm{yr}\end{array}$ & $\begin{array}{c}30-74 \\
\mathrm{yr}\end{array}$ & $\begin{array}{l}\text { Singles, couples, } \\
\text { families }\end{array}$ & Detached/semi-detached & $\begin{array}{l}\text { Small towns, } \\
\text { suburbs, rural }\end{array}$ & $\begin{array}{l}\text { Above } \\
\text { average }\end{array}$ & $\begin{array}{l}\text { Professional/blue } \\
\text { white collar }\end{array}$ \\
\hline $\begin{array}{l}\text { Comfortable mixed } \\
\text { tenure } \\
\text { neighbourhoods }\end{array}$ & 8.42 & $\begin{array}{c}5-15 \\
\mathrm{yr}\end{array}$ & $\begin{array}{c}30-74 \\
\mathrm{yr}\end{array}$ & $\begin{array}{l}\text { Singles, couples. } \\
\text { Some retired }\end{array}$ & Detached/semi-detached/flats & $\begin{array}{l}\text { Small towns, } \\
\text { suburbs, rural }\end{array}$ & Average & $\begin{array}{l}\text { Professional/blue } \\
\text { white collar }\end{array}$ \\
\hline $\begin{array}{l}\text { Less affluent family } \\
\text { neighbourhoods }\end{array}$ & 16.48 & $\begin{array}{c}5-19 \\
\mathrm{yr}\end{array}$ & $\begin{array}{c}30-64 \\
\mathrm{yr}\end{array}$ & $\begin{array}{l}\text { Singles, couples, } \\
\text { families }\end{array}$ & Semi-detached/terraced & $\begin{array}{l}\text { Small towns, } \\
\text { suburbs }\end{array}$ & $\begin{array}{l}\text { Below } \\
\text { average }\end{array}$ & $\begin{array}{l}\text { Professional/blue } \\
\text { white collar }\end{array}$ \\
\hline $\begin{array}{l}\text { Less affluent singles } \\
\text { and students in urban } \\
\text { areas }\end{array}$ & 5.7 & $\begin{array}{c}0-19 \\
\mathrm{yr}\end{array}$ & $\begin{array}{c}20-44 \\
\mathrm{yr}\end{array}$ & $\begin{array}{l}\text { Singles, couples, } \\
\text { students }\end{array}$ & Terraced/flats & $\begin{array}{l}\text { Inner cities } \\
\text { suburbs }\end{array}$ & $\begin{array}{l}\text { Above } \\
\text { average }\end{array}$ & $\begin{array}{l}\text { Professional/blue } \\
\text { white collar }\end{array}$ \\
\hline $\begin{array}{l}\text { Poorer family and } \\
\text { single parent } \\
\text { households }\end{array}$ & 10.69 & $\begin{array}{c}0-19 \\
\mathrm{yr}\end{array}$ & $\begin{array}{c}20-59 \\
\text { yrs }\end{array}$ & $\begin{array}{l}\text { Singles, couples, } \\
\text { families, single } \\
\text { parents }\end{array}$ & Semi-detached/terraced/flats & $\begin{array}{l}\text { Small towns, } \\
\text { suburbs }\end{array}$ & Low & $\begin{array}{l}\text { Professional/blue } \\
\text { white collar, } \\
\text { unskilled }\end{array}$ \\
\hline $\begin{array}{l}\text { Poorer council } \\
\text { tenants including } \\
\text { many single parents }\end{array}$ & 11.53 & $\begin{array}{c}0-19 \\
\mathrm{yr}\end{array}$ & $\begin{array}{c}20-59 \\
\mathrm{yr}\end{array}$ & $\begin{array}{l}\text { Singles, single, } \\
\text { parents. Some } \\
\text { retired }\end{array}$ & Terraced/flats & $\begin{array}{l}\text { Small towns, } \\
\text { suburbs }\end{array}$ & Very low & $\begin{array}{l}\text { Professional/blue } \\
\text { white collar, } \\
\text { unskilled }\end{array}$ \\
\hline
\end{tabular}

Source: the centre for Value Chain Research $\left(\mathrm{VCR}^{2}\right)$, Kent Business School.

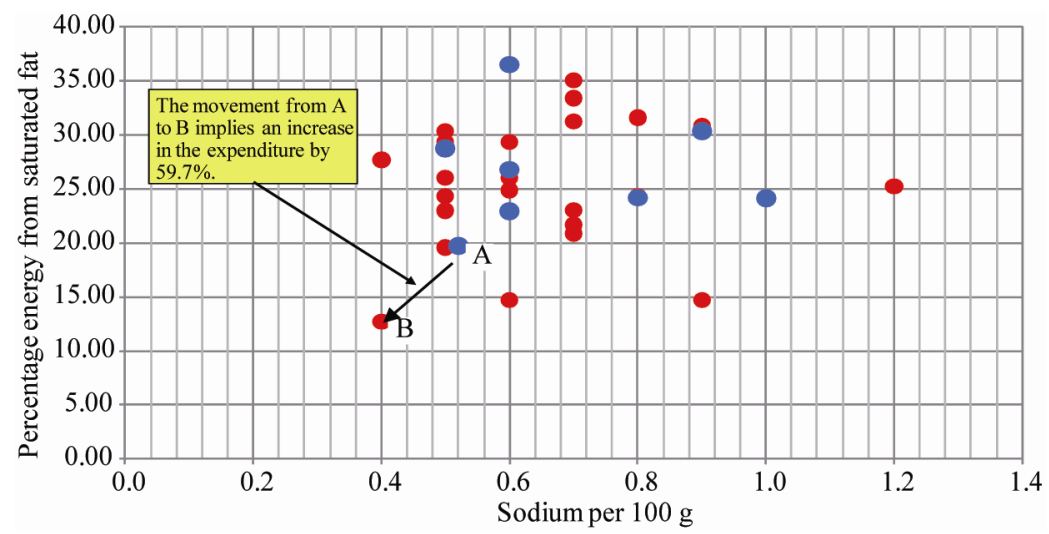

Note: blue dots indicate the top-10 sausages in terms of expenditure and red are the remaining ones.

Figure 1. Relationship between percentage of energy from saturated fat and sodium per $100 \mathrm{~g}$ (excluding salami). 


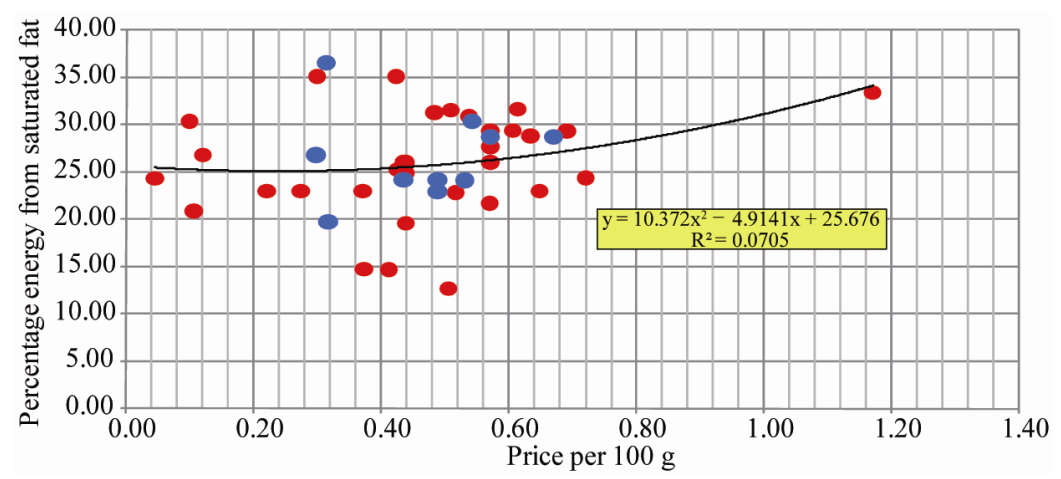

Note: blue dots indicate the top-10 sausages in terms of expenditure and red are the remaining ones.

Figure 2. Relationship between percentage of energy from saturated fat and price per $100 \mathrm{~g}$ (excluding salami).

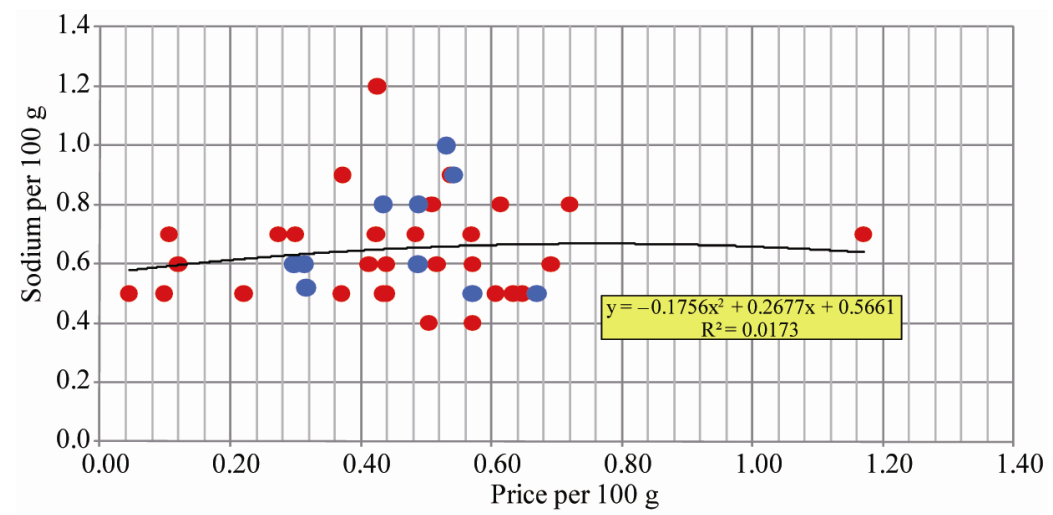

Note: blue dots indicate the top-10 sausages in terms of expenditure and red are the remaining ones.

Figure 3. Relationship between sodium per $100 \mathrm{~g}$ and price per $100 \mathrm{~g}$ (excluding salami).

fat or sodium content. This may indicate, as also pointed out in Figure 1, that consumers' personal preferences play an important role in the choice of sausages. This is because the demand is not concentrated on the cheaper categories and therefore, the issue of taste and preferences might be an important demand component. The second aspect is the variability of prices and nutritional content within the sausage category. In other words, consumers could (if they wish) move to sausages with better nutritional characteristics, probably at a lower price.

Table 3 presents expenditure share (i.e., share in the total expenditure on sausages of the group), the energy from saturated fat, and sodium content of the most bought sausage per group (note that the share in the most popular sausage in each group only commands 6 to 9 percent of expenditure). Clearly, from a health point of view there is an ample margin for improvement. However, it is necessary to analyse whether this can be done without a substantive increase in expenditure.

A shown in Table 3, based on the lifestage classification, i.e., older families and young adults (i.e., Groups 1 and 4) are the ones with the poorest choice (in health terms, i.e., as regards the percentage of energy from saturated fats and the quantity of sodium) of sausages. In comparison to these groups, young families (Group 5) choose a healthier option; however, it still could be improved when compared with the healthiest option.

As regards the CAMEO categories, Groups 4 and 7 (i.e., Less Affluent Singles and Students and Poorer White and Blue Collar Workers, respectively) are ones with the unhealthiest choice. Note however, that socioeconomic status does not necessarily imply unhealthy choice as several poorer groups (e.g., Poorer Council Tenants-Many Single Parents) chose a sausage with less fat than more affluent groups (e.g., Affluent HomeOwners). It is interesting to note that the wealthier groups (i.e., Affluent Home-Owners, Wealthy Retired Neighbourhoods and Young and Affluent Singles) had sausages with lower sodium content as their first choice.

In addition to Table 3, four comparisons were made to analyse the change in expenditure towards a movement to healthier choices. First, how each one of the lifestage and CAMEO groups ranked the healthiest choice in their 
expenditure (Table 4); second, the change in expenditure per $100 \mathrm{~g}$ by lifestage and CAMEO groups with respect to the healthiest choice (Table 5); third, the change in expenditure per $100 \mathrm{~g}$ by lifestage and CAMEO groups with respect to the choice with the second least fat (Table 6), and fourth, was similar to the previous one but with respect to the choice with the second least sodium (Table 7).

Table 4 comprises three panels. The first panel shows the ranking of the healthiest sausage according to the lifestage and CAMEO classifications. The second and the third panels show similar information by with respect to the sausage with the second least fat and with the second least sodium, respectively.
None of the groups, lifestage or CAMEO, had the healthiest sausage amongst their top 10 and when all the groups are put together it comes in ranking 16. A similar result is obtained with respect to the second healthiest sausage with respect to fat. In the case of the sausage with the second lowest sodium content, none of the lifestage categories selected it amongst the top-10. However, in the case of the CAMEO groups, it was the wealthier groups that ranked the second least sodium sausage more highly (ranked 9 in Group 1, 7 in Groups 9 and 12 in Group 10).

Tables 5-7 are similar in the sense that they measure the change in expenditure per $100 \mathrm{~g}$ of moving from the top-10 choices (ranked by expenditure) per group to

Table 3. Expenditure, energy from saturated fat, and sodium of the most purchased sausage per group.

\begin{tabular}{|c|c|c|c|c|c|c|c|}
\hline $\begin{array}{l}\text { Lifestage } \\
\text { Group }\end{array}$ & $\begin{array}{l}\text { Expenditure } \\
\text { share \% }\end{array}$ & $\begin{array}{c}\text { Energy from } \\
\text { saturated fat \% }\end{array}$ & $\begin{array}{l}\text { Sodium per } \\
100 \mathrm{~g}(\mathrm{~g})\end{array}$ & $\begin{array}{c}\text { CAMEO } \\
\text { Group }\end{array}$ & $\begin{array}{l}\text { Expenditure } \\
\text { share \% }\end{array}$ & $\begin{array}{c}\text { Energy from } \\
\text { saturated fat \% }\end{array}$ & $\begin{array}{l}\text { Sodium per } \\
100 \mathrm{~g}(\mathrm{~g})\end{array}$ \\
\hline Group 1 & 6.29 & 30.37 & 0.90 & Group 1 & 7.00 & 28.72 & 0.50 \\
\hline Group 2 & 6.84 & 24.18 & 0.80 & Group 2 & 6.58 & 24.18 & 0.80 \\
\hline Group 3 & 9.92 & 24.18 & 0.80 & Group 3 & 6.47 & 24.18 & 0.80 \\
\hline Group 4 & 6.35 & 30.37 & 0.90 & Group 4 & 6.12 & 30.37 & 0.90 \\
\hline \multirow[t]{6}{*}{ Group 5} & 6.77 & 22.94 & 0.60 & Group 5 & 7.03 & 24.18 & 0.80 \\
\hline & & & & Group 6 & 7.08 & 24.18 & 0.80 \\
\hline & & & & Group 7 & 5.72 & 30.37 & 0.90 \\
\hline & & & & Group 8 & 6.41 & 24.18 & 0.80 \\
\hline & & & & Group 9 & 7.25 & 28.72 & 0.50 \\
\hline & & & & Group 10 & 6.70 & 28.72 & 0.50 \\
\hline Altogether & 6.49 & 24.18 & 0.80 & Altogether & 6.49 & 24.18 & 0.80 \\
\hline Healthiest & 1.80 & 12.70 & 0.40 & Healthiest & 1.80 & 12.70 & 0.40 \\
\hline
\end{tabular}

Source: [1]. Note 1: ranking with respect to 49 products. See Methods section for a description of the groups.

Table 4. Rankings of healthy sausages in terms of expenditure.

\begin{tabular}{|c|c|c|c|c|c|c|c|c|c|c|c|}
\hline \multicolumn{4}{|c|}{ Healthiest sausage } & \multicolumn{4}{|c|}{ Sausage with the second least fat } & \multicolumn{4}{|c|}{ Sausage with the second least sodium } \\
\hline $\begin{array}{c}\text { Lifestage } \\
\text { Group }\end{array}$ & Ranking & $\begin{array}{l}\text { CAMEO } \\
\text { Group }\end{array}$ & Ranking & $\begin{array}{c}\text { Lifestage } \\
\text { Group }\end{array}$ & Ranking & $\begin{array}{c}\text { CAMEO } \\
\text { Group }\end{array}$ & Ranking & $\begin{array}{c}\text { Lifestage } \\
\text { Group }\end{array}$ & Ranking & $\begin{array}{c}\text { CAMEO } \\
\text { Group }\end{array}$ & Ranking \\
\hline Group 1 & 17 & Group 1 & 28 & Group 1 & 20 & Group 1 & 19 & Group 1 & 18 & Group 1 & 9 \\
\hline Group 2 & 16 & Group 2 & 15 & Group 2 & 18 & Group 2 & 19 & Group 2 & 15 & Group 2 & 17 \\
\hline Group 3 & 16 & Group 3 & 16 & Group 3 & 20 & Group 3 & 26 & Group 3 & 19 & Group 3 & 20 \\
\hline Group 4 & 17 & Group 4 & 20 & Group 4 & 22 & Group 4 & 25 & Group 4 & 14 & Group 4 & 13 \\
\hline \multirow[t]{5}{*}{ Group 5} & 17 & Group 5 & 13 & Group 5 & 19 & Group 5 & 27 & Group 5 & 20 & Group 5 & 35 \\
\hline & & Group 6 & 16 & & & Group 6 & 21 & & & Group 6 & 24 \\
\hline & & Group 7 & 16 & & & Group 7 & 27 & & & Group 7 & 20 \\
\hline & & Group 8 & 13 & & & Group 8 & 18 & & & Group 8 & 19 \\
\hline & & Group 10 & 27 & & & Group 10 & 25 & & & Group 10 & 12 \\
\hline Altogether & 16 & Altogether & 16 & Altogether & 20 & Altogether & 20 & Altogether & 17 & Altogether & 17 \\
\hline
\end{tabular}

Source: [1]. Note 1: ranking with respect to 49 products. See Methods section for a description of the groups. 
Table 5. Percentage change in expenditure per $100 \mathrm{~g}$, by lifestage and CAMEO category, to move to the healthiest sausage.

\begin{tabular}{|c|c|c|c|c|c|c|c|c|c|c|c|c|c|c|c|c|}
\hline Expenditure & & Life & stage gr & oup & & & & & & CAME & group & & & & & Altogether \\
\hline Order & $\begin{array}{c}\text { Group } \\
1\end{array}$ & $\begin{array}{c}\text { Group } \\
2\end{array}$ & $\begin{array}{c}\text { Group } \\
3\end{array}$ & $\begin{array}{c}\text { Group } \\
4\end{array}$ & $\begin{array}{c}\text { Group } \\
5\end{array}$ & $\begin{array}{c}\text { Group } \\
1\end{array}$ & $\begin{array}{c}\text { Group } \\
2\end{array}$ & $\begin{array}{c}\text { Group } \\
3\end{array}$ & $\begin{array}{c}\text { Group } \\
4\end{array}$ & $\begin{array}{c}\text { Group } \\
5\end{array}$ & $\begin{array}{c}\text { Group } \\
6\end{array}$ & $\begin{array}{c}\text { Group } \\
7\end{array}$ & $\begin{array}{c}\text { Group } \\
8\end{array}$ & $\begin{array}{c}\text { Group } \\
9\end{array}$ & $\begin{array}{c}\text { Group } \\
10\end{array}$ & \\
\hline $1 \mathrm{st}$ & -6.9 & 16.2 & 16.2 & -6.9 & 3.5 & -24.6 & 16.2 & 16.2 & -6.9 & 16.2 & 16.2 & -6.9 & 16.2 & -24.6 & -11.6 & 16.2 \\
\hline $2 \mathrm{nd}$ & 16.2 & -6.9 & 60.9 & 16.2 & 16.2 & -11.6 & -6.9 & 60.9 & 16.2 & -6.9 & -6.9 & 16.2 & 3.5 & -11.6 & 16.2 & -6.9 \\
\hline $3 \mathrm{rd}$ & 60.9 & -11.6 & 3.3 & 60.9 & -6.9 & 16.2 & -11.6 & -6.9 & -0.8 & 60.9 & 60.9 & 60.9 & -11.6 & 16.2 & -24.6 & 60.9 \\
\hline 4 th & -11.6 & 60.9 & 59.7 & -11.6 & -24.6 & -11.6 & -24.6 & 3.5 & -11.6 & -4.9 & -4.9 & -11.6 & -24.6 & -11.6 & -11.6 & 3.5 \\
\hline 5 th & -4.9 & -24.6 & -4.9 & 3.5 & 60.9 & -11.6 & 60.9 & -24.6 & -11.6 & 69.4 & 3.5 & -24.6 & 60.9 & -11.6 & -6.9 & -11.6 \\
\hline 6th & -24.6 & 3.5 & -11.6 & -24.6 & -11.6 & -6.9 & 3.5 & -11.6 & -24.6 & 59.7 & 69.4 & -11.6 & -6.9 & 3.5 & -11.6 & -24.6 \\
\hline 7th & 3.5 & -4.9 & -24.6 & -11.6 & 59.7 & 3.5 & 3.3 & 3.3 & 60.9 & 3.3 & 59.7 & -27.0 & 3.3 & -11.6 & -0.8 & 3.3 \\
\hline 8th & 3.3 & 3.3 & 69.4 & -11.6 & 3.3 & 60.9 & -11.6 & -4.9 & -11.6 & 3.5 & 3.3 & 3.3 & -4.9 & 3.3 & 60.9 & -4.9 \\
\hline 9th & 69.4 & 69.4 & -6.9 & -4.9 & -4.9 & -11.6 & -4.9 & -11.6 & -55.8 & -11.6 & -11.6 & 15.1 & -11.6 & -6.9 & 3.3 & 59.7 \\
\hline 10th & 59.7 & -11.6 & -11.6 & -0.8 & -56.9 & 3.3 & 59.7 & -11.6 & 3.5 & 84.7 & -24.6 & 3.5 & -11.6 & 60.9 & -20.4 & 69.4 \\
\hline
\end{tabular}

Source: [1]. Note 1: see Methods section for a description of the groups.

Table 6. Percentage change in expenditure per $100 \mathrm{~g}$, by lifestage and CAMEO category, with respect to moving to the sausage with the second least fat content).

\begin{tabular}{cccccccccccccccccccc}
\hline Expenditure & \multicolumn{1}{c}{ Lifestage group } & \multicolumn{1}{c}{ CAltogether } \\
\hline Order & Group & Group & Group & Group & Group & Group & Group & Group & Group & Group & Group & Group & Group & Group & Group \\
& 1 & 2 & 3 & 4 & 5 & 1 & 2 & 3 & 4 & 5 & 6 & 7 & 8 & 9 & 10 \\
\hline 1st & -24.0 & -5.1 & -5.1 & -24.0 & -15.5 & -38.5 & -5.1 & -5.1 & -24.0 & -5.1 & -5.1 & -24.0 & -5.1 & -38.5 & -27.8 & -5.1 \\
2nd & -5.1 & -24.0 & 31.4 & -5.1 & -5.1 & -27.8 & -24.0 & 31.4 & -5.1 & -24.0 & -24.0 & -5.1 & -15.5 & -27.8 & -5.1 & -24.0 \\
3rd & 31.4 & -27.8 & -15.6 & 31.4 & -24.0 & -5.1 & -27.8 & -24.0 & -19.0 & 31.4 & 31.4 & 31.4 & -27.8 & -5.1 & -38.5 & 31.4 \\
4th & -27.8 & 31.4 & 30.4 & -27.8 & -38.5 & -27.8 & -38.5 & -15.5 & -27.8 & -22.4 & -22.4 & -27.8 & -38.5 & -27.8 & -27.8 & -15.5 \\
5th & -22.4 & -38.5 & -22.4 & -15.5 & 31.4 & -27.8 & 31.4 & -38.5 & -27.8 & 38.3 & -15.5 & -38.5 & 31.4 & -27.8 & -24.0 & -27.8 \\
6th & -38.5 & -15.5 & -27.8 & -38.5 & -27.8 & -24.0 & -15.5 & -27.8 & -38.5 & 30.4 & 38.3 & -27.8 & -24.0 & -15.5 & -27.8 & -38.5 \\
7th & -15.5 & -22.4 & -38.5 & -27.8 & 30.4 & -15.5 & -15.6 & -15.6 & 31.4 & -15.6 & 30.4 & -40.4 & -15.6 & -27.8 & -19.0 & -15.6 \\
8th & -15.6 & -15.6 & 38.3 & -27.8 & -15.6 & 31.4 & -27.8 & -22.4 & -27.8 & -15.5 & -15.6 & -15.6 & -22.4 & -15.6 & 31.4 & -22.4 \\
9th & 38.3 & 38.3 & -24.0 & -22.4 & -22.4 & -27.8 & -22.4 & -27.8 & -63.9 & -27.8 & -27.8 & -6.0 & -27.8 & -24.0 & -15.6 & 30.4 \\
10th & 30.4 & -27.8 & -27.8 & -19.0 & -64.8 & -15.6 & 30.4 & -27.8 & -15.5 & 50.8 & -38.5 & -15.5 & -27.8 & 31.4 & -35.0 & 38.3 \\
\hline
\end{tabular}

Source: [1]. Note 1: see Methods section for a description of the groups.

the healthiest sausage (Table 5), to the one with second healthiest with respect to fat (Table 6) and to the second healthiest with respect to sodium content (Table 7). For instance, the first row of Table 5 shows the change in expenditure that each one of the groups would need to make to move from their sausage with the highest share of expenditure to the healthiest one. Thus, if all the categories are considered, consumers would be required to increase their expenditure by 16 per cent to move to the healthiest sausage.

Table 5 shows that it is possible for some of the groups to move from their current top 10 sausages to the healthiest without increasing their expenditure. Indeed, approximately half of the moves to the healthiest sausage would involve a decrease in expenditure. If one concentrates the analysis on the sausage with the highest expen- diture share, then one can see that Groups 1 and 4, in the lifestage groups (i.e., those with the worst choices in health terms) could improve their choice in terms of health and also reduce their expenditure.

Similar to the previous result, some groups under the CAMEO classification could improve their choice in term of health and save money. This is particularly important for groups with poorer income such as Groups 4 and 7, although it is also true for the most affluent categories (Groups 1, 9 and 10).

If the replacement is undertaken with respect to the sausage with the second least content of fat (see Table 6), then it would be possible for all the groups, not only to improve their health choice, but also save money as shown by the first row of the table. A different way of interpreting this result is that the choice of sausage is not 
Table 7. Percentage change in expenditure per $100 \mathrm{~g}$, by lifestage and CAMEO category, with respect to moving to the sausage with the second least sodium content.

\begin{tabular}{|c|c|c|c|c|c|c|c|c|c|c|c|c|c|c|c|c|}
\hline Expenditure & & Life & stage gr & coup & & & & & & CAME & group & & & & & Altogether \\
\hline Order & $\begin{array}{c}\text { Group } \\
1\end{array}$ & $\begin{array}{c}\text { Group } \\
2\end{array}$ & $\begin{array}{c}\text { Group } \\
3\end{array}$ & $\begin{array}{c}\text { Group } \\
4\end{array}$ & $\begin{array}{c}\text { Group } \\
5\end{array}$ & $\begin{array}{c}\text { Group } \\
1\end{array}$ & $\begin{array}{c}\text { Group } \\
2\end{array}$ & $\begin{array}{c}\text { Group } \\
3\end{array}$ & $\begin{array}{c}\text { Group } \\
4\end{array}$ & $\begin{array}{c}\text { Group } \\
5\end{array}$ & $\begin{array}{c}\text { Group } \\
6\end{array}$ & $\begin{array}{c}\text { Group } \\
7\end{array}$ & $\begin{array}{c}\text { Group } \\
8\end{array}$ & $\begin{array}{c}\text { Group } \\
9\end{array}$ & $\begin{array}{c}\text { Group } \\
10\end{array}$ & \\
\hline $1 \mathrm{st}$ & 5.3 & 31.5 & 31.5 & 5.3 & 17.0 & -14.8 & 31.5 & 31.5 & 5.3 & 31.5 & 31.5 & 5.3 & 31.5 & -14.8 & 0.0 & 31.5 \\
\hline 2nd & 31.5 & 5.3 & 82.0 & 31.5 & 31.5 & 0.0 & 5.3 & 82.0 & 31.5 & 5.3 & 5.3 & 31.5 & 17.0 & 0.0 & 31.5 & 5.3 \\
\hline $3 \mathrm{rd}$ & 82.0 & 0.0 & 16.8 & 82.0 & 5.3 & 31.5 & 0.0 & 5.3 & 12.2 & 82.0 & 82.0 & 82.0 & 0.0 & 31.5 & -14.8 & 82.0 \\
\hline 4th & 0.0 & 82.0 & 80.7 & 0.0 & -14.8 & 0.0 & -14.8 & 17.0 & 0.0 & 7.5 & 7.5 & 0.0 & -14.8 & 0.0 & 0.0 & 17.0 \\
\hline 5 th & 7.5 & -14.8 & 7.5 & 17.0 & 82.0 & 0.0 & 82.0 & -14.8 & 0.0 & 91.6 & 17.0 & -14.8 & 82.0 & 0.0 & 5.3 & 0.0 \\
\hline 6th & -14.8 & 17.0 & 0.0 & -14.8 & 0.0 & 5.3 & 17.0 & 0.0 & -14.8 & 80.7 & 91.6 & 0.0 & 5.3 & 17.0 & 0.0 & -14.8 \\
\hline 7th & 17.0 & 7.5 & -14.8 & 0.0 & 80.7 & 17.0 & 16.8 & 16.8 & 82.0 & 16.8 & 80.7 & -17.4 & 16.8 & 0.0 & 12.2 & 16.8 \\
\hline 8th & 16.8 & 16.8 & 91.6 & 0.0 & 16.8 & 82.0 & 0.0 & 7.5 & 0.0 & 17.0 & 16.8 & 16.8 & 7.5 & 16.8 & 82.0 & 7.5 \\
\hline 9th & 91.6 & 91.6 & 5.3 & 7.5 & 7.5 & 0.0 & 7.5 & 0.0 & -50.0 & 0.0 & 0.0 & 30.2 & 0.0 & 5.3 & 16.8 & 80.7 \\
\hline 10th & 80.7 & 0.0 & 0.0 & 12.2 & -51.2 & 16.8 & 80.7 & 0.0 & 17.0 & 108.9 & -14.8 & 17.0 & 0.0 & 82.0 & -9.9 & 91.6 \\
\hline
\end{tabular}

Source: [1]. Note 1: see Methods section for a description of the groups.

necessarily led by economic reasons, as consumers could make healthier choices at a lower price. Certainly, other factors probably influence the choice of purchase, such as the palatability of the sausage.

The analysis with respect to the second sausage in terms of sodium content shows results that are dramatically different from the ones with respect to fat. Thus, the table shows that most of the groups would need to increase their expenditure in order to purchase such a relatively low sodium sausage. Moreover, when all the groups are considered together, the movement from the top sausage in terms of expenditure share to that with the second least content in terms of sodium would imply an increase in the expenditure of 31.5 percent. If the price of healthier choices is a barrier to improved consumers' choice, then promotion of the consumption of sausages with less sodium would be a more difficult task.

As regards the previous result, the conclusions from the study by [30] as regards British sausages are interesting. They state that no correlation was found between fat content and juiciness, and between salt content and perceived saltiness. The lack of association between fat and juiciness seems to be due to the fact that the latter depends not only on the intramuscular fat content but also on the amount of moisture retained after cooking, which itself depends on various factors: the moisture level of the uncooked sausage, the amount of added rusk, any added soya protein and the amount of added salt and phosphate. With respect to the low association between salt content and saltiness, they noted that the degree of perceived saltiness does not just depend on the salt content per se, but that it is also affected by the background composition of the product being assessed, including the level of fat, the lean content and the presence of mono- sodium glutamate (MSG)

The results of [30] indicate that it possible for suppliers to improve the nutritional value of the existing diet without changing much its palatability. In fact, this could be a more straightforward way to improve the quality of the Scottish diet since the results of our analysis show that movements towards healthier choices may imply for some consumers a higher cost.

\section{Conclusions}

Overall, the purpose of the paper has been to analyse consumers' choices of sausages using supermarket data, and whether moving from sausages with a high percentage of energy from saturated fats and a high content of sodium per $100 \mathrm{~g}$ to healthier ones, would result in an expenditure increase.

The results indicate that the top-ten consumers' choices are far from being the healthiest ones and there is plenty of scope for improvement. It is important to note that it is not possible in all cases to replace the currently consumed sausage with a healthier version (i.e., lower saturated fat or lower sodium content) for the same price per $100 \mathrm{~g}$. However, this is possible in many cases, especially in the case of sausages with high fat content.

In the case of salt, the results indicate that movements towards sausages with low sodium content would in several instances increase the expenditure. However, this is a situation where science can give a hand by modifying the composition of the products without changing much their taste. Thus, one of the solutions (besides educational campaigns directed to consumers) would be to improve the nutritional value of the existing diet by decrease the fat and salt content of the processed meat. However, to confirm the validity of this suggestion 
would require consideration of the cost implications for the sausage manufacturer.

There is a consensus amongst nutritionists and meat scientists alike, that higher quality, lean and low fat meat products should be preferred and higher fat content products such as regular sausages should be consumed in moderation $[7,31,32]$. Furthermore, higher quality meat products, and especially sausage, could then significantly contribute to a better diet of consumers who very often are not prepared to avoid or even decrease their consumption of meat. Moreover meat can be a valuable part of the human diet as it provides important nutrients such as essential amino acids, vitamins and minerals [33].

Finally, we consider that there is a need for industry reformulation to produce better quality processed meat which is lower in saturated fat and salt but just as palatable as the higher fat and salt alternatives in order to improve the diet of especially poorer groups of consumers in Scotland. However, the technological implications of such changes in products may involve significant cost increases that when passed onto customers can impair the purchase of lower fat/salt products by low income consumers.

\section{Acknowledgements}

This paper was financially supported by the Scottish Government Research Programme, Theme 5 "Efficient and resilient supply chains for food". We would like to thank the comments received from Ms. Anne Milne from the Food Standards Agency-Scotland, Professor Andrew Fearne from the Centre for Value Chain Research (VCR2), Kent Business School for providing the data and Mr. Luca Cacciolati for extracting the data for the original study. The opinions in the paper are solely authors' responsibility.

\section{REFERENCES}

[1] C. Revoredo-Giha, B. Kupiec-Teahan, P. Leat, A. Fearne and L. Cacciolatti, "An Exploration of the Use of a Dataset of Supermarket Purchases for the Analysis of Red Meat Purchases in Scotland," 2009.

http://www.foodbase.org.uk/admintools/reportdocuments/ 376-1-654_S14046_final_report_29-8-09pdf.pdf

[2] Food Standards Agency (FSA), "Eat Well, Live Well," 2009. http://www.eatwell.gov.uk/healthydiet/fss/

[3] K. Matthews, M. Blades and M. Strong, "Survey of the Nutritional Content of Meat Products on Sale in Scotland from Butchers' Shops and Multiple Retailers," Nutrition and Food Science, Vol. 33, No. 3, 2003, pp. 98-104. doi:10.1108/00346650310476087

[4] N. Darmon and A. Drewnowski, "Does Social Class Predict Diet Quality?" American Journal of Clinical Nutrition, Vol. 87, No. 5, 2008, pp. 1107-1117.

[5] Key Note, "Meat and Meat Products," 2008.
[6] Agriculture and Horticulture Development Board (AHDB), "UK Pig Market Update," 2008.

[7] A. Daviglus and K. H. Pirzada, "Meat Consumption and Cardiovascular Disease," In: International Encyclopedia of Public Health, Academic Press, Oxford, 2008, pp. 281308. doi:10.1016/B978-012373960-5.00541-4

[8] Mintel, "Cheapest on Display Food," 2008.

[9] L. M. Hoelscher, J. W. Savell, J. M. Harris, H. R. Cross and K. S. Rhee, "Effect of Initial Fat Level and Cooking Method-Cholesterol Content and Caloric Value of Ground Beef Patties," Journal of Food Science, Vol. 52, No. 4, 1987, pp. 882-885.

doi:10.1111/j.1365-2621.1987.tb14233.x

[10] R. Chizzolini, E. Zanardi, V. Dorigoni and S. Ghidini, "Calorific Value and Cholesterol Content of Normal and Low-Fat Meat and Meat Products," Trends in Food Science and Technology, Vol. 10, No. 4-5, 1999, pp. 119128. doi:10.1016/S0924-2244(99)00034-5

[11] E. Cengiz and N. Gökoğlu, "Effects of Fat Reduction and Fat Replacer Addition on Some Quality Characteristics of Frankfurter-Type Sausages," International Journal of Food Science \& Technology, Vol. 42, No. 3, 2007, pp. 366-372. doi:10.1111/j.1365-2621.2006.01357.x

[12] M. Ruusunen and E. Puolanne, "Reducing Sodium Intake from Meat Products," Meat Science, Vol. 70, No. 3, 2005, pp. 531-541. doi:10.1111/j.1365-2621.2006.01357.x

[13] F. Jimenes-Colmenero, "Relevant Factors in Strategies for Fat Reduction in Meat Products," Trends in Food Science \& Technology, Vol. 11, No. 2, 2000, pp. 56-66. doi:10.1016/S0924-2244(00)00042-X

[14] Scottish Office, "Scotland's Health a Challenge to Us All. The Scottish Diet: Report of a Working Party to the Chief Medical Officer for Scotland," 1993.

http://www.scotland.gov.uk/Resource/Doc/47060/001296 $0 . p d f$

[15] Scottish Diet Action Group, "Eating for Health: A Diet Action Plan for Scotland," 1996. http://www.scotland.gov.uk/library/documents/diet-00.htm

[16] Scottish Executive, "Improving Health in Scotland-The Challenge," 2003.

http://www.scotland.gov.uk/library5/health/ihis-00.asp

[17] M. Blades, "An Examination of Data on the Scottish Diet," Nutrition and Food Science, Vol. 34, No. 6, 2004, pp. 246-252. doi:10.1108/00346650410568291

[18] World Cancer Research Fund/American Institute for Cancer Research, "Food, Nutrition, Physical Activity, and the Prevention of Cancer: A Global Perspective," 2007. http:// www.dietandcancerreport.org

[19] A. J. Cross, M. F. Leitzmann, M. H. Gail, A. R. Hollenbeck, A. Schatzkin and R. Sinha, "A Prospective Study of Red and Processed Meat Intake in Relation to Cancer Risk," Public Library of Science Medicine, Vol. 4, No. 12, 2007, pp. 325-335.

[20] W. L. Wrieden, K. L. Barton, J. Armstrong and G. McNeil, "A Review of Food Consumption and Nutrient Intakes from National Surveys in Scotland: Comparison to the Scottish Dietary Targets," 2006.

http://www.food.gov.uk/multimedia/pdfs/scotdietrytarg.pdf 
[21] Scottish Government, "Healthy Eating Active Living: An Action Plan to Improve Diet, Physical Activity and Tackle Obesity (2008-2011)," Edinburgh, 2009.

[22] A. Inglis, K. Ball and D. Crawford, "Why Do Women of Low Socioeconomic Status Have Poorer Dietary Behaviours than Women of Higher Socioeconomic Status? A Qualitative Exploration," Appetite, Vol. 45, No. 3, 2005, pp. 334-343. doi:10.1016/j.appet.2005.05.003

[23] M. Maillot, N. Darmon, M. Darmon, L. Lafay and A. Drewnowski, "Nutrient-Dense Food Groups Have High Energy Costs: An Econometric Approach to Nutrient Profiling," Journal of Nutrition, Vol. 137, No. 7, 2007, pp. 1815-1820.

[24] P. Rozin, "The Integration of Biological, Social, Cultural, and Psychological Influences on Food Choice," In: R. Shepherd and M. Raats, Eds., The Psychology of Food Choice, CABI, Surrey, 2006. doi:10.1079/9780851990323.0019

[25] Mintel, "Red Meat," 2008.

[26] P. Kähkönen and H. Tuorila, "Consumer Responses to Reduced and Regular Fat Content in Different Products: Effects of Gender, Involvement and Health Concern," Food Quality and Preference, Vol. 10, No. 2, 1999, pp. 83-91. doi:10.1016/S0950-3293(98)00043-3

[27] A. V. A. Resurreccion, "Sensory Aspects of Consumer Choices for Meat and Meat Products," Meat Science, Vol. 66, No. 1, 2004, pp. 11-20.
doi:10.1016/S0309-1740(03)00021-4

[28] R. Solheim and M. R. Ellekjær, "Sensory Quality of Low-Fat Sausages Affected by Fat Substitutes," Food Quality and Preference, Vol. 4, No. 3, 1993, pp. 127-131. doi:10.1016/0950-3293(93)90155-Y

[29] D. B. Homer, K. R. Matthews and C. C. Warkup, "The Acceptability of Low Fat Sausages," Nutrition \& Food Science, Vol. 30, No. 2, 2000, pp. 67-72. doi:10.1108/00346650010314287

[30] P. R. Sheard, E. Hope, S. I. Hughes, A. Baker and G. R. Nute, "Eating Quality of UK-Style Sausages Varying in Price, Meat Content, Fat Level and Salt Content," Meat Science, Vol. 85, No. 1, 2010, pp. 40-46. doi:10.1016/i.meatsci.2009.12.001

[31] L. M. Valsta, H. Tapanainen and S. Männistö, "Meat Fats in Nutrition," Meat Science, Vol. 70, No. 3, 2005, pp. 525-530. doi:10.1016/i.meatsci.2004.12.016

[32] A. J. McAfee, E. M. McSorley, G. J. Cuskelly, B. W. Moss, J. M. W. Wallace, M. P. Bonham and A. M. Fearon, "Red Meat Consumption: An Overview of the Risks and Benefits," Meat Science, Vol. 84, No. 1, 2010, pp. 1-13. doi:10.1016/j.meatsci.2009.08.029

[33] H. Biesalski, "Meat as a Component of a Healthy DietAre There Any Risks or Benefits If Meat Is Avoided in the Diet?" Meat Science, Vol. 70, No. 3, 2005, pp. 509524. doi:10.1016/j.meatsci.2004.07.017 